\title{
Methylisoindigo and Its Bromo-Derivatives Are Selective Tyrosine Kinase Inhibitors, Repressing Cellular Stat3 Activity, and Target CD133+ Cancer Stem Cells in PDAC
}

\author{
Jana Tegethoff ${ }^{1, \dagger}$, Roland Bischoff ${ }^{2, \dagger}$, Sawsan Saleh ${ }^{1}$, Biljana Blagojevic ${ }^{1}$, Karl-Heinz Merz ${ }^{2}$ \\ and Xinlai Cheng $1, *$ (D) \\ 1 Department of Pharmacy and Molecular Biotechnology, Division of Pharmaceutical Biology, \\ University of Heidelberg, Im Neuenheimer Feld 364, D-69120 Heidelberg, Germany; \\ jana.tegethoff@gmail.com (J.T.); sawsanalisaleh@gmail.com (S.S.); blagojevicbiljana@yahoo.com (B.B.) \\ 2 Department of Chemistry, Division of Food Chemistry and Toxicology, University of Kaiserslautern, \\ Erwin-Schrödinger-Strasse 52, D-67663 Kaiserslautern, Germany; roland@bischoffonline.de (R.B.); \\ karlheinz_merz@yahoo.de (K.-H.M.) \\ * Correspondence: x.cheng@uni-heidelberg.de; Tel.: +49-6221-546431; Fax: +49-6221-544884 \\ + These authors contributed equally to this work.
}

Received: 7 August 2017; Accepted: 11 September 2017; Published: 13 September 2017

\begin{abstract}
Indirubin is an active component of the herbal ingredient 'Danggui Longhui wan', which was used for the treatment of inflammation and chronic myeloid leukemia in China. The recent study showed its derivative methylisoindigo (also known as meisoindigo) preferentially targeting cancer stem cells (CSCs) in interference with AMPK and LKB1, the cellular metabolic sensors. In this study, we screened the effect of meisoindigo on a panel of 300 protein kinases and found that it selectively inhibited Stat3-associated tyrosine kinases and further confirmed its activity in cell based assays. To gain a deeper insight into the structure-activity relationship we produced 7 bromo-derivatives exhausting the accessible positions on the bisindole backbone except for in the 4-position due to the space limitation. We compared their anti-proliferative effects on tumor cells. We found that 6-bromomeisoindigo showed improved toxicity in company with increased Stat3 inhibition. Moreover, we detected that 6-bromomeisoindigo induced apoptosis of $95 \%$ of CD133+ pancreatic cancer cells. Considering that CD133 is a common marker highly expressed in a range of CSCs, our results imply the potential application of 6-bromomeisoindigo for the treatment of CSCs in different types of cancers.
\end{abstract}

Keywords: indirubin; meisoindigo; cancer stem cells; Stat3 inhibitor; selective protein kinase inhibitor; TCM; structure-activity-relationship

\section{Introduction}

Indigo, a natural 2,2'-bisindole, is one of the most successful natural pigments with an annual consumption of several thousand tons (Figure 1) [1]. Its 3,2'-isoform, also known as indirubin, is used in China for treatment of chronic myeloid leukemia (CML). Clinical trials in the 1970s proofed the anti-leukemic effect of indirubin with mild side-effects [2]. However, the potential of indirubin for clinical application is limited by its extremely low water solubility. A number of follow-up studies were performed by either chemical modification [3-5] or lipid-based formulation [6-8] to improve its bioavailability. Isoindigo is a synthetic 3,3'-bisindole (Figure 1). Its $N$-methylated derivative (methylisoindigo, also known as meisoindigo) showed less side-effects and better bioavailability in animals and patients [2]. 
Results from recent studies indicated that the anti-tumorigenic effect of indirubin and its derivatives is majorly based on the potent inhibition of multiple protein kinases $[9,10]$. The identified target kinases include glycogen synthase kinase $3 \beta$ (GSK-3 $\beta$ ), cyclin-dependent kinases (CDKs) [9,11,12], CK2 [13], and IGF-1R [3]. By contrast, little is known about the effect of meisoindigo on protein kinases [14].

Recently, Hoheisel and his co-workers established a new primary pancreatic cell line, JoPaca-1, derived from a male patient suffering from pancreatic ductal adenocarcinoma [15]. This cell line contains a large population of cancer stem cells (CSCs) expressing stem cell markers CD133 [16,17]. Using this cell line as a model, we found that meisoindigo preferentially kills CD133 positive cells due to the inference with cellular metabolic signaling pathways involving AMPK and LKB1 [18]. CSCs are a sub-population of cancer cells that obtains the main features of stem cells: self-renewal, the capacity to strongly proliferate, and to develop into multiple lineages [18]. Former results revealed that they contribute to tumor initiation, formation of metastases, drug-resistances, and relapse in several cancers [19], like pancreatic cancer [20] and acute myeloid leukemia [21]. Thus, drugs inhibiting CSCs might be pioneering drugs for development of more efficient chemotherapy with expectations of eradicating metastases and preventing relapse [22].

In vitro and in vivo studies showed that indirubin derivatives are potent Src family kinases (SFKs) inhibitors [12,23-28]. Since SFKs are major kinases to regulate the activation of signal transducer and activator of transcription 3 (Stat3) [29], indirubin derivatives remarkably inhibit cellular Stat3 activity [26-28]. Stat3 is a key mediator of proliferation, cell cycle progression, angiogenesis, survival, and differentiation. Persistently active Stat3 has been found in various tumor types and tissues including leukemias [30], cervical [31], colorectal [32], and pancreatic cancer [33], which contributes to tumor initiation, progression, invasion, migration, and formation of metastases [34,35]. In addition, Stat3 plays an important role in the maintenance of stem cell-like properties such as self-renewal in embryonic stem cells and pancreatic CSCs [36,37].<smiles>O=C1NC(=C2Nc3ccccc3C2=O)C1=O</smiles><smiles>O=C1Nc2ccccc2C1=C1C(=O)Nc2ccccc21</smiles>

Isoindigo<smiles>O=C1Nc2ccccc2/C1=C1\Nc2ccccc2C1=O</smiles><smiles>CN1C(=O)/C(=C2\C(=O)Nc3ccccc32)c2ccccc21</smiles>

1-Methylisoindigo (meisoindigo)

Figure 1. Structures of bisindoles: indigo, indirubin, isoindigo, and N-methylisoindigo (meisoindigo).

Thus, Stat3 could be a potential target of meisoindigo involved in its negative regulation of CD133+ CSCs. In this work, we performed protein kinase profiling using a panel of 300 protein kinases and found that meisoindigo selectively inhibited tyrosine kinases related to Stat 3 activity in vitro as well as in vivo, confirmed by cell-based assays. We investigated the structure-activity relationship by studying the anti-proliferative effects of newly synthesized novel bromo-meisoindigos. The results show that only 6-bromo-meisoindigo enhanced the inhibition on both Stat3 activity and 
cell proliferation, suggesting the limitation of access for chemical modification towards a protein kinase inhibitor.

\section{Results and Discussion}

\subsection{Chemistry}

The lack of systematic evaluation of the chemical accessibility of positions on bisindole backbone inspired us to synthesize various bromo-meisoindigos. Those novel meisoindigo derivatives (1-7) were obtained by acidic condensation of corresponding bromoisatins with either methyloxindoles or methylated bromoisatins with oxindoles, as showed in Scheme 1 [13,18]. Bromo-isatins were synthesized by acidic cyclization of bromo-isonitrosoacetanilides achieved in the reaction of bromoanilines with chloral hydrate and hydroxylamine hydrochloride [3]. In the case of 3-bromoaniline, the formation of a mixture of 4- and 6-bromoisatins was observed and could be separated by fractionated precipitation. Bromoisatins reacted further with dimethylsulfate in dried dimethylformamide (DMF) containing $\mathrm{NaH}$ as base under nitrogen atmosphere to afford methylated products. Because of the steric hindrance, we produced 4'-bromo-meisoindigo in an extremely low yield $(<10 \%)$ and failed to synthesize 4-bromo-1-meisoindigo. All chemical structures of compounds are listed in Table 1.

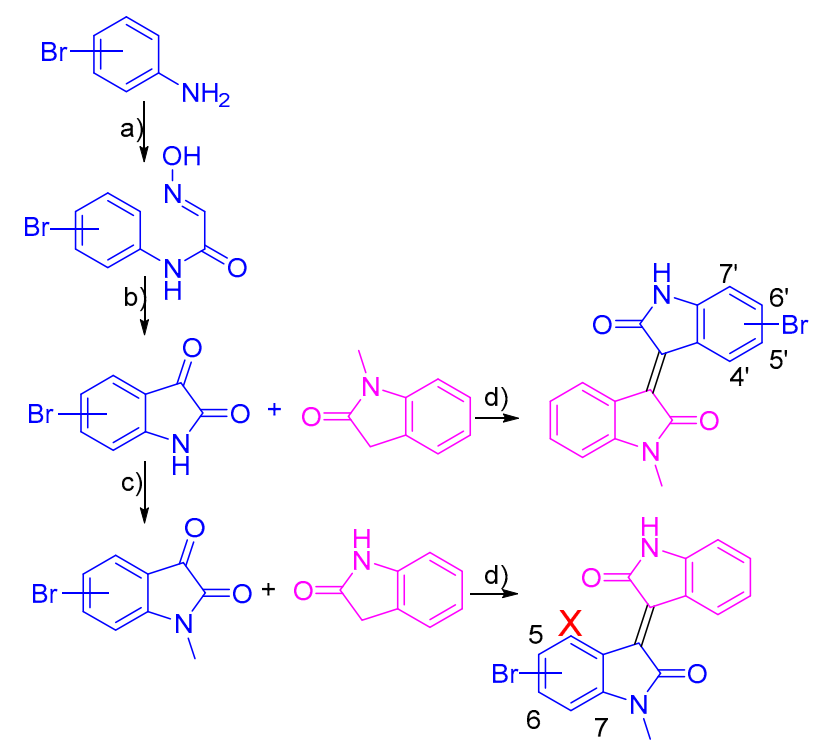

Scheme 1. Synthesis of bromo-meisoindigo derivatives (a) $\mathrm{CCl}_{3} \mathrm{CH}(\mathrm{OH})_{2}, \mathrm{NH}_{2} \mathrm{OH} \cdot \mathrm{HCl}, \mathrm{H}_{2} \mathrm{O}, \mathrm{Na}_{2} \mathrm{SO}_{4}$; (b) $\mathrm{H}_{2} \mathrm{SO}_{4}$; (c) $\left(\mathrm{CH}_{3} \mathrm{O}\right) \mathrm{SO}_{2}, \mathrm{NaH}$, DMF; (d) $\mathrm{HOAc} / \mathrm{HCl} 100: 1,120-128{ }^{\circ} \mathrm{C}, 3.5 \mathrm{~h}$, X: unable to obtain the derivative in this position due to steric hindrance.

Table 1. Chemical structures of novel-bromomeisoindigos.

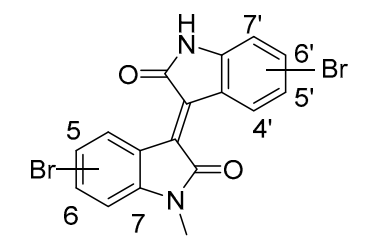

\begin{tabular}{cccc}
\hline $\mathbf{N r}$ & Compounds & $\mathrm{Nr}$ & Compounds \\
\hline & & 4 & $4^{\prime}$-bromo-meisoindigo \\
$\mathbf{1}$ & 5-bromo-meisoindigo & $\mathbf{5}$ & $5^{\prime}$-bromo-meisoindigo \\
$\mathbf{2}$ & 6-bromo-meisoindigo & $\mathbf{6}$ & $6^{\prime}$-bromo-meisoindigo \\
$\mathbf{3}$ & 7-bromo-meisoindigo & 7 & $7^{\prime}$-bromo-meisoindigo \\
\hline
\end{tabular}




\subsection{Biology}

\subsubsection{Meisoindigo Is a Selective Stat3-Related Tyrosine Kinase Inhibitor}

Results from biological studies implied that meisoindigo might target distinct protein kinases in comparison to indirubin [9]. To gain a better insight in its mechanism of action we screened the inhibitory effect of meisoindigo in a panel of 300 human protein kinases. As shown in Figure 2a and supplementary information, meisoindigo $(20 \mu \mathrm{M})$ was a highly selective tyrosine kinase inhibitor with a selective score of 0.07 (calculated as the number of kinases with residual activity $<50 \%$ divided by 300). Interestingly, most of them are involved in the regulation of Stat3 activity $[34,38,39]$, including growth factor-related receptor tyrosine kinases, insulin-like growth factor receptor 1 (IGF-R1), fibroblast growth factor receptor 2 (FGF-R2), vascular endothelia growth factor receptor 2 (VEGF-R2), and FGF-R3 [39,40], as well as Trk-B, Ron, Ret, and Mertk which activate Stat3 directly or via interleukin 6 and MAPK/Erk-associated signaling [41-44] and Src family kinases (SFKs), such as Lyn, Fyn, Src, Lck, Yes [29,45-47], Breast tumor kinase (BRK), Fes, and Fer [48-50].

(a)

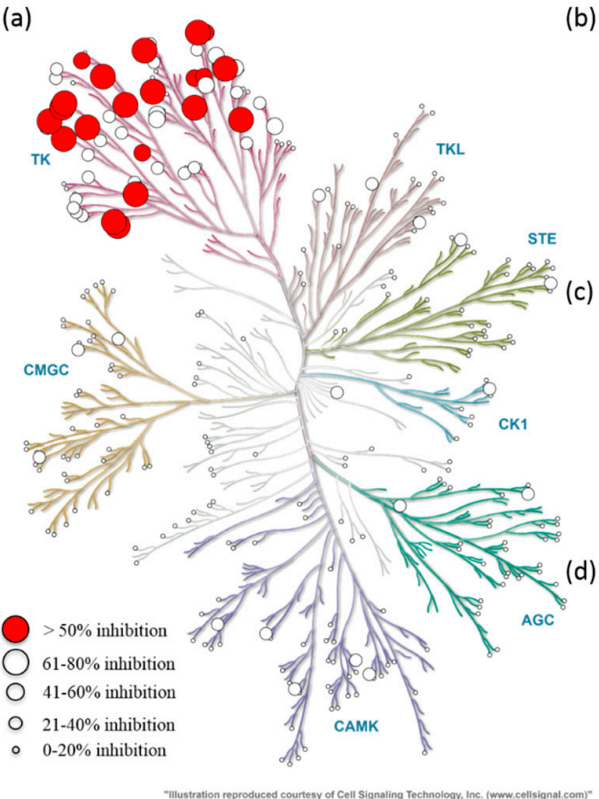

(b)
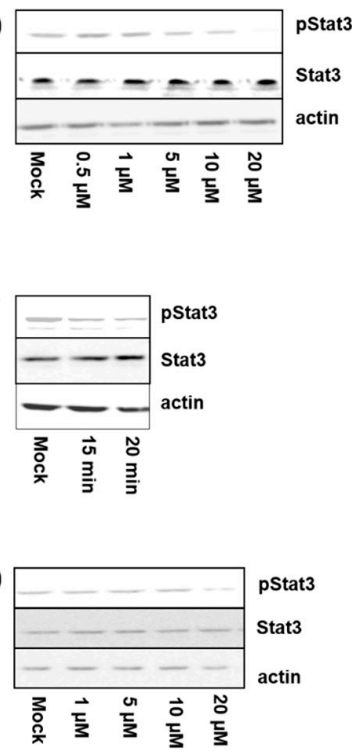
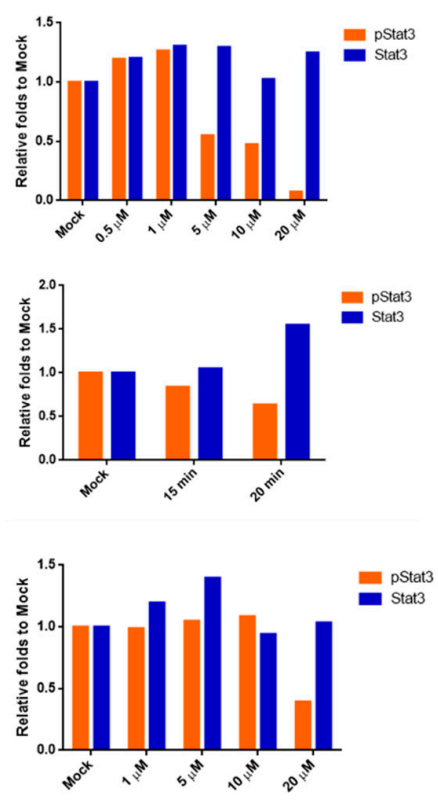

Figure 2. (a) Kinase profiling of meisoindigo at $20 \mu \mathrm{M}$ against 300 human kinases. Circles show inhibited kinases, the size indicates the strength of inhibition. Kinases inhibited more than $50 \%$ are marked red including only tyrosine kinases (TKs). The graphic was generated using KinMap beta developed by BioMedX; (b) Meisoindigo inhibited Stat3 activation in HeLa cells in a dose-dependent manner. HeLa cells were incubated with meisoindigo for $30 \mathrm{~min}$. The whole cell lysate was used for immunoblot. Specific antibodies against Stat3 and phospho-Stat3 (Y705) were applied. $\beta$-actin served as loading control and $0.1 \%$ DMSO as mock; (c) Meisoindigo inhibited Stat3 activation in HeLa cells in a time-dependent manner. Cells were treated at $5 \mu \mathrm{M}$ as indicated and immunoblot was performed; (d) Meisoindigo inhibited Stat 3 activation in JoPaca-1 cells in a dose-dependent manner. JoPaca-1 cells were treated for $2 \mathrm{~h}$ as indicated and immunoblot was performed.

\subsubsection{Meisoindigo Inhibits Cellular Stat3 Activation in Time and Concentration Dependent Manner}

We investigated the influence of meisoindigo on Stat 3 activity in HeLa cells by measuring the level of phospho-Stat3. The immunoblot result confirmed that meisoindigo inhibited cellular Stat3 up a concentration of $5 \mu \mathrm{M}$ (Figure $2 \mathrm{~b}$ ), which occurred as early as 15 min upon treatment (Figure 2c). JoPaca- 1 cells are more resistant and the reduction of phospho-Stat 3 was observed upon treatment of $20 \mu \mathrm{M}$ for $2 \mathrm{~h}$ (Figure 2d). In both cell lines pan-Stat3 remained unaffected. Given that persistent Stat3 activation drives tumor initiation and progression [34] and mediates stemness in pancreatic CSCs, 
the anti-proliferative effect of meisoindigo and its inhibition on CSCs reported previously [18] might partially depend on Stat3.

\subsubsection{Anti-Proliferative Effect of Novel Bromo-Meisoindigos}

We tested anti-proliferative effects of newly synthesized bromo-meisoindigos on HeLa, HCT116, and JoPaca-1 cells. Out of seven compounds 6-, 7- and 5'-bromo-meisoindigo showed the reduction of cellular viability with $\mathrm{IC}_{50}$ values lower than $50 \mu \mathrm{M}$ in all three cell lines, while the introduction in the 5- and 7'-positions completely blocked the activity. It seems that the substituent in the 4-position interrupts the planar structure of meisoindigo and results in the inactivation. Comparison to the binding of indirubin to CDK2 in ATP-binding pocket [9], H-bridges might be formed between $1^{\prime}$-NH-CO of meisoindigos and target protein kinases (Figure 3), which could explain the strong impact caused by substitution in 5- and 7'-position. Moreover, we measured the toxicity of meisoindigo and its 6-bromo-derivative in human primary fibroblasts and found that both were not toxic at the concentration lower than $50 \mu \mathrm{M}$ (Table 2), implying that meisoindigos preferentially target cancer cells. Thus, 6-Bromo-meisoindigo emerged as the most active compound and was selected for further analysis.

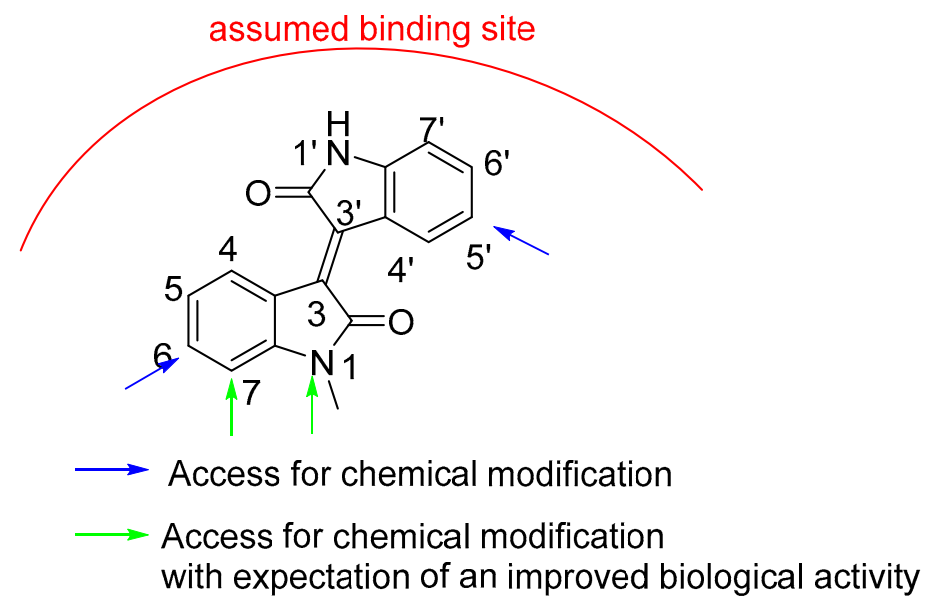

Figure 3. Assumed binding site and potential accesses for chemical modification of isoindigo. 
Table 2. IC50 values of compounds in HeLa, HCT116, and JoPaca-1 cells tested by MTT assay.

\begin{tabular}{|c|c|c|c|c|c|c|c|c|c|}
\hline $\begin{array}{l}\text { IC }_{50} / \text { Cell } \\
\text { Line }\end{array}$ & & Meisoindigo & $\begin{array}{c}\text { 5-Bromo- } \\
\text { Meisoindigo }\end{array}$ & $\begin{array}{c}\text { 6-Bromo- } \\
\text { Meisoindigo }\end{array}$ & $\begin{array}{c}\text { 7-Bromo- } \\
\text { Meisoindigo }\end{array}$ & $\begin{array}{c}4^{\prime} \text {-Bromo- } \\
\text { Meisoindigo }\end{array}$ & $\begin{array}{c}5^{\prime} \text {-Bromo- } \\
\text { Meisoindigo }\end{array}$ & $\begin{array}{c}\text { 6'-Bromo- }^{\prime} \text {-Beisoindigo } \\
\text { Meisolis }\end{array}$ & $\begin{array}{l}7^{\prime} \text {-Bromo- } \\
\text { Meisoindigo }\end{array}$ \\
\hline HeLa & $72 \mathrm{~h}$ & $9.53 \pm 1.09$ & $>100$ & $5.84 \pm 0.40$ & $24.69 \pm 6.64$ & $>50$ & $18.32 \pm 3.22$ & $17.71 \pm 1.98$ & $>100$ \\
\hline HCT116 & $72 \mathrm{~h}$ & $9.09 \pm 1.13$ & $>100$ & $7.55 \pm 1.05$ & $26.34 \pm 9.63$ & n.t. & $21.96 \pm 3.22$ & $16.17 \pm 1.73$ & $>100$ \\
\hline JoPaca-1 & $72 \mathrm{~h}$ & $13.92 \pm 1.39$ & $>100$ & $10.52 \pm 1.67$ & $13.15 \pm 0.99$ & $>50$ & $13.04 \pm 1.49$ & $>100$ & $>100$ \\
\hline $\mathrm{HF}$ & $72 \mathrm{~h}$ & $>50$ & n.t. & $>50$ & n.t. & n.t. & n.t. & n.t. & n.t. \\
\hline
\end{tabular}

n.t.: not tested. 


\subsubsection{6-Bromo-Meisoindigo Inhibits Stat3 Activity and Induces Cell Cycle Arrest in HeLa Cells}

Upon phosphorylation at tyrosine 705 (Y705), Stat3 is activated, dimerizes, and translocates into the nucleus to promote downstream gene expression $[1,38,39]$. Thus, nucleic translocation of cytosolic Stat3 is of importance for activation of Stat3 downstream gene expression [51]. We recruited immunocytochemistry and clearly showed the reduction of nucleic phospho-Stat 3 upon treatment with either meisoindigo $(5 \mu \mathrm{M})$ or 6-bromo-meisoindigo $(1 \mu \mathrm{M})$ in HeLa cells (Figure $4 \mathrm{a})$. Immunoblot further confirmed the reduction in the level of total cellular phospho-Stat3 up a concentration of $1 \mu \mathrm{M}$ (Figure 4b), while pan-Stat3 remained constant. Since Stat3 regulates cell cycle progression [52], we determined cell cycle progression in living HeLa cells using FACS (fluorescence-activated cell sorting) analysis. In the presence of 6-bromo-meisoindigo, cells accumulated in the G2 and M phases instead of progressing to G1 phase (Figure 4c).
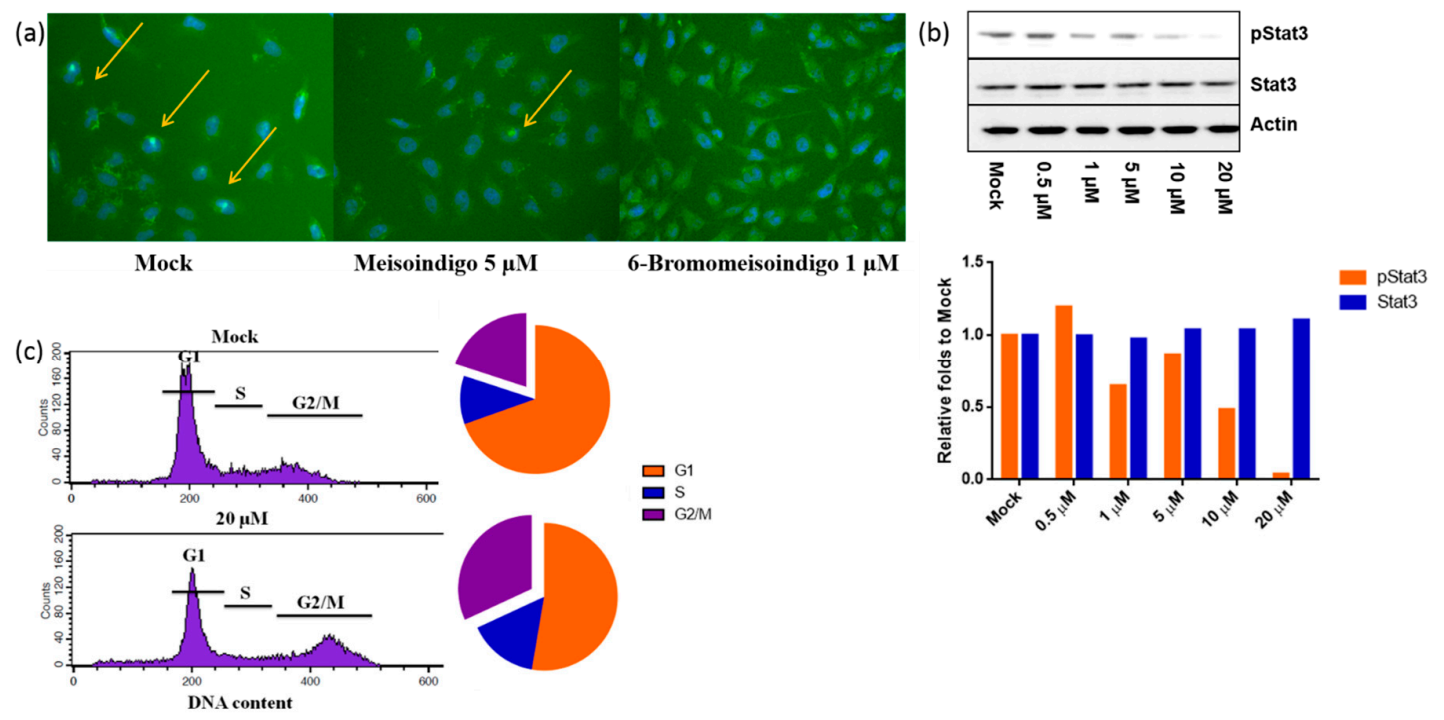

Figure 4. (a) Meisoindigo and 6-bromo-meisoindigo reduced Stat3 activity in HeLa cells. Cells were treated as indicated and fixed in formaldehyde. Specific antibodies against phospho-Stat3 (Y705) and Hoechst stain were used for immunocytochemistry assay; (b) 6-bromo-meisoindigo reduced Stat 3 activity in HeLa cells in a dose-dependent manner. HeLa cells were incubated with compound for $30 \mathrm{~min}$. The whole cell lysate was used for immunoblot. Specific antibodies against Stat3 and phospho-Stat3 (Y705) were applied. $\beta$-actin served as loading control and 0.1\% DMSO as mock; (c) 6-bromo-meisoindigo induced a G2/M cell cycle arrest in HeLa cells, determined by FACS analysis.

\subsubsection{6-Bromo-Meisoindigo Inhibits Stat3 Activity in Jopaca-1 Cells}

We analyzed Stat 3 activity in JoPaca-1 cells in the presence/absence of 6-bromo-meisoindigo by immunoblot and found $10 \mu \mathrm{M}$ was sufficient to block phospho-Stat3 (Figure 5a). qRT-PCR using cDNA synthesized with random primers from RNA isolated from 6-bromo-meisoindigo-treated Jopaca-1 cells exhibited a clear reduction in the level of c-Jun and MAFF expression (Figure 5b), downstream genes of Stat3 [53], while Stat3 expression was unaffected. c-Jun is a transcription factor that mediates progression through G2/M phase and inhibition of apoptosis [54,55], in consistence that 6-bromo-meisoindigo induced cell-cycle arrest at G2/M in HeLa cells. MAFF is a transcription factor that regulates oxidative stress response [56], suggesting disruption of cellular homeostasis might be involved in meisoindigo and derivatives-induced apoptosis, like we showed previously [18].

We also compared the level of four apoptosis-related genes expression (Figure 5b). c-Myc, an oncogene that is overactive in numbers of tumors and contributes to tumor initiation and progression [57], was slightly suppressed in presence of 6-bromo-meisoindigo or meisoindigo for $24 \mathrm{~h}$. p16 and p21 are CDK inhibitors and play important roles in the regulation of cell proliferation. 
Expression of both was strongly increased by 6-bromo-meisoindigo and meisoindigo suggesting that observed cell cycle arrest at least partially depended on their inhibition of CDKs. ATF3 is another apoptosis related gene and inhibits the activity of p53, a key mediator of apoptosis [58]. The expression of ATF3 was reduced upon treatment with 6-bromo-meisoindigo for two hours. Results from phosphor-protein kinase microarray analysis (Figure 5c) confirmed that the activity of GSK3ß and FAK was not affected by meisoindigo derivatives, while reduction of phosphor-Akt was observed probably due to the inhibition of IGF-1R (Figure 2a and supplementary information). Thus, ATF3 may play a role in the induction of apoptosis by meisoindigos. Taken together, we showed that 6-bromo-meisoindigo inhibited Stat3 activity in JoPaca-1 cells and altered the expression of Stat3 related genes involved in the regulation of apoptosis and cell cycle.

(a)

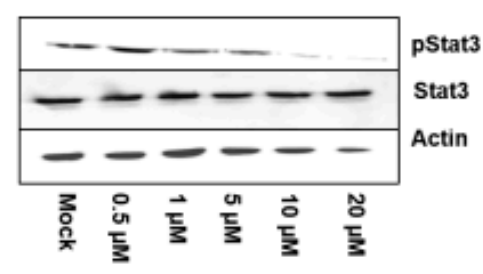

(b)

6-bromo-meisoindigo $2 \mathrm{~h}$ meisoindigo $24 \mathrm{~h}$

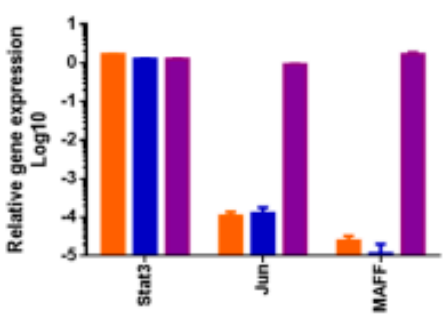

transcription factor expression

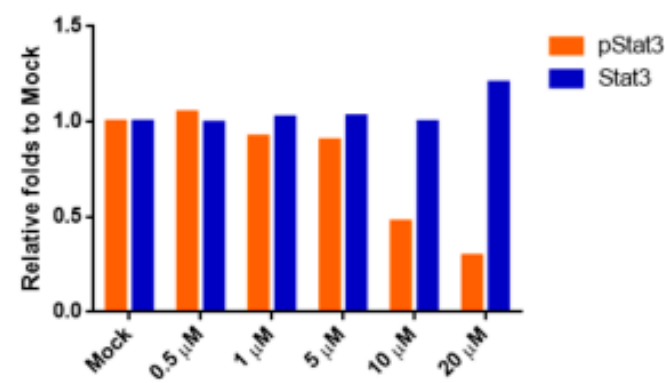

(c)

Figure 5. (a) 6-Bromo-meisoindigo inhibits Stat3 activation in JoPaca-1 cells in a dose-dependent manner. Cells were incubated with compound for $30 \mathrm{~min}$. The whole cell lysate was used for immunoblot. Specific antibodies against Stat3 and phospho-Stat3 (Y705) were applied. $\beta$-actin served as loading control and $0.1 \%$ DMSO as mock; (b) 6-bromo-meisoindigo altered expression of Stat3 related transcription factors and apoptosis-related genes; (c) Protein microarray analysis of phosphorylation of protein kinases in 6-bromo-meisoindigo-treated Jopaca-1 cells.

\subsubsection{6-Bromo-Meisoindigo Induces Apoptosis in CD133+ Jopaca-1 Cells}

Our recent results showed that meisoindigo suppressed CD133 expression, preferentially killed CD133+ cells, and thereby impacted on the stemness of CSCs in JoPaca-1 cells [18]. We examined the effect of newly synthesized bromo-meisoindigos on CD133+ cells in JoPaca-1 and found the general inhibition of CD133 expression in the presence of bromo-meisoindigos (Figure 6a). Among those, $5^{\prime}$-bromo-meisoindigo (Figure 6a) showed the highest activity. Previous results demonstrated that CD133+ CSCs are very resistant to chemotherapeutic agents [15]. We interestingly found that nearly $60 \%$ and $90 \%$ of CD133+ CSCs were annexin v positive in the presence of 6 -bromo-meisoindigo at 5 and $20 \mu \mathrm{M}$ (Figure 6b), implicating the high potential of 6-bromo-meisoindigo for treatment of CD133+ CSCs, which might depend on its Stat3 inhibition. 
(a)

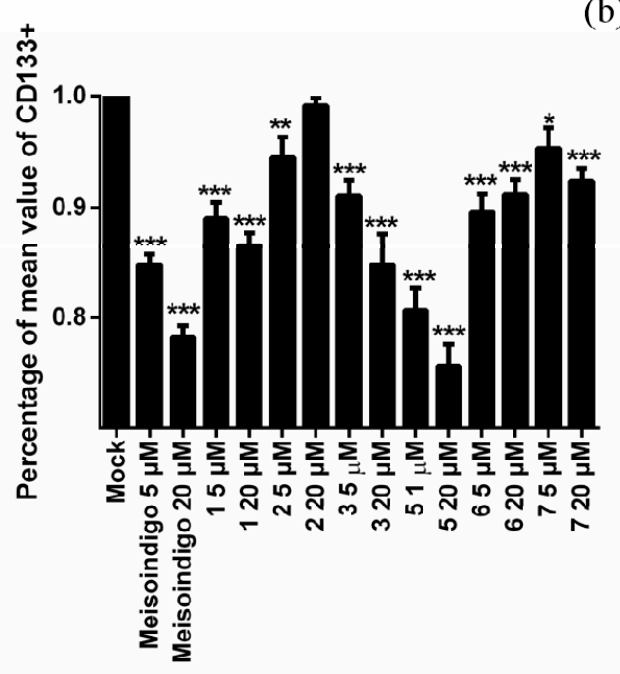

(b)
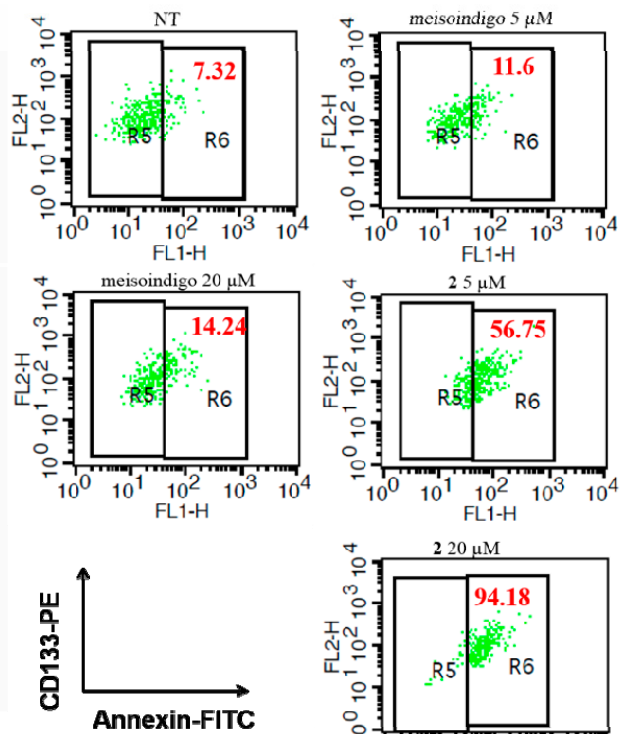

Figure 6. (a) Bromo-meisoindigos reduced CD133+ population in JoPaca-1 cells. The percentage of CD133 expression was determined by FACS analysis and the mean value was normalized to mock treatment; (b) Meisoindigo and 6-bromo-meisoindigo induced apoptosis in JoPaca-1 cells. Cells were treated as indicated for $24 \mathrm{~h}$ and FACS analysis was performed.

\section{Experimental Section}

\subsection{Materials}

pStat3Tyr705 (9145), Stat3 (9139) primary antibodies, and Alexa Flour 488 Phalloidin (8878) were purchased from Cell Signaling Technology (Danvers, MA, USA). $\beta$-actin primary antibody and HRP-coupled secondary anti-mouse and anti-rabbit antibodies were from Santa Cruz Biotechnology (Santa Cruz, CA, USA). Fluorochrome-coupled Goat IgG anti-rabbit IgG Alexa Flour 594 was bought from dianova (Hamburg, Germany). DMEM, RPMI 1640 medium, fetal bovine serum (FBS), Penicillin/Streptomycin (Pen/Strep) and PBS were purchased from Gibco by Life Technologies (Carlsbad, CA, USA).

\subsection{Synthesis of Bromo-Meisoindigo Derivatives}

A mixture of 2-bromoaniline or 3-bromoaniline $(110 \mathrm{mmol}, 18.9 \mathrm{~g})$, chloral hydrate $(118.8 \mathrm{mmol}$, $19.6 \mathrm{~g})$, anhydrous sodium sulfate $(880 \mathrm{mmol}, 125 \mathrm{~g})$, and hydroxylamine hydrochloride $(347.6 \mathrm{mmol}$, $24.2 \mathrm{~g}$ ) in water $(700 \mathrm{~mL})$ was heated under reflux for $25 \mathrm{~min}$ to form a yellow precipitate. $50 \mathrm{vmL}$ of ethanol was added after that and left to boil for another $4 \mathrm{~min}$ before filtration. The resulted isonitrosoacetanilide was then heated with sulfuric acid $(150 \mathrm{~mL})$ at $70{ }^{\circ} \mathrm{C}$ for about $10 \mathrm{~min}$ then poured into ice water to form an orange precipitate. When using 3-bromoaniline, an extra step of separation is required by solving the resulted mixture in $0.25 \mathrm{M} \mathrm{NaOH}(1 \mathrm{~L})$, filtering it, then adding acetic acid $(100 \mathrm{~mL})$ to afford 4-bromoistain as a precipitate. 6-Bromoistin can be then obtained when lowering the $\mathrm{pH}$ of the solution to 1 by hydrochloric acid $37 \%$.

All substituted bromo-isatins were methylated by stirring $(22 \mathrm{mmol}, 4.97 \mathrm{~g}$ ) with sodium hydride ( $2 \mathrm{mmol}, 0.968 \mathrm{~g}$ ) and dimethylsulfate $(23.1 \mathrm{mmol}, 2.19 \mathrm{~mL})$ in dried DMF $(50 \mathrm{~mL})$ under nitrogen atmosphere. The resulting mixture was poured after $2 \mathrm{~h}$ in ice water $(100 \mathrm{~mL})$ to form an orange precipitate.

The methylated bromo-isatins ( $2 \mathrm{mmol}, 0.480 \mathrm{~g}$ ) were treated after that with oxindole $(2 \mathrm{mmol}$, $0.226 \mathrm{~g})$ in a 100:1 mixture of glacial acetic acid and hydrochloric acid $37 \%(12 \mathrm{~mL})$ in reflux for about $3 \mathrm{~h}$. Then, they were poured in ice water $(50 \mathrm{~mL})$ to afford 5-, 6- and 7-bromomeisoindigo. 
While $4^{\prime}-, 5^{\prime}-, 6^{\prime}$ - and $7^{\prime}$-bromomeisoindigo were obtained by reacting unmethylated bromo-isatins ( $2 \mathrm{mmol}, 0.452 \mathrm{~g}$ ) with 1-methyloxindole $(2 \mathrm{mmol}, 0.294 \mathrm{~g})$ in the same conditions. The resulted precipitates were washed with water, ethanol $(2 \times 10 \mathrm{~mL})$, and diethylether $(2 \times 10 \mathrm{~mL})$ then dried.

\subsubsection{5-Bromo-1-Meisoindigo}

Yield: 70\%. ${ }^{1} \mathrm{H}-\mathrm{NMR}\left(400 \mathrm{MHz}, \mathrm{DMSO}, d_{6}\right) \delta \mathrm{ppm} 3.19(\mathrm{~s}, 3 \mathrm{H}), 6.83\left(\mathrm{dd},{ }^{3} J=7.8 \mathrm{~Hz},{ }^{4} J=0.5 \mathrm{~Hz}, 1 \mathrm{H}\right)$ $6.96(\mathrm{~m}, 1 \mathrm{H}), 6.97\left(\mathrm{~d},{ }^{3} J=8.4 \mathrm{~Hz}, 1 \mathrm{H}\right), 7.35\left(\mathrm{td},{ }^{3} J=7.6 \mathrm{~Hz},{ }^{4} J=1.1 \mathrm{~Hz}\right), 7.58\left(\mathrm{dd},{ }^{3} J=8.4 \mathrm{~Hz},{ }^{4} J=2.1 \mathrm{~Hz}\right)$, $9.06\left(\mathrm{dd},{ }^{3} J=8.1 \mathrm{~Hz},{ }^{4} J=0.5 \mathrm{~Hz}\right), 9.31\left(\mathrm{~d},{ }^{4} J=2.0 \mathrm{~Hz}, 1 \mathrm{H}\right), 10.94(\mathrm{~s}, 1 \mathrm{H}) .{ }^{13} \mathrm{C}-\mathrm{NMR}(100 \mathrm{MHz}, \mathrm{DMSO}$, $\left.d_{6}\right) \delta$ ppm 26.6, 110.2, 110.7, 114.0, 121.8, 121.9, 123.0, 130.2, 131.1, 131.5, 133.8, 134.8, 135.6, 144.4, 145.0, 167.2, 169.3. Anal. calcd. for $\mathrm{C}_{17} \mathrm{H}_{11} \mathrm{BrN}_{2} \mathrm{O}_{2}$ : C 57.49, H 3.12, N 7.89; found: C 57.44, H 3.18, N 793. HRMS (ESI) calculated $m / z: 376.9896$; found $\mathrm{C}_{17} \mathrm{H}_{11} \mathrm{BrN}_{2} \mathrm{O}_{2} ; m / z: 376.9896[\mathrm{M}+\mathrm{H}]^{+}$.

\subsubsection{6-Bromo-1-Meisoindigo}

Yield: 83\%. ${ }^{1} \mathrm{H}-\mathrm{NMR}\left(400 \mathrm{MHz}, \mathrm{DMSO}, d_{6}\right) \delta \mathrm{ppm} 3.17(\mathrm{~s}, 3 \mathrm{H}), 6.79\left(\mathrm{dd},{ }^{3} J=7.7 \mathrm{~Hz},{ }^{4} J=0.5 \mathrm{~Hz}\right.$, $1 \mathrm{H}), 6.93\left(\mathrm{td},{ }^{3} J=7.8 \mathrm{~Hz},{ }^{4} J=1.1 \mathrm{~Hz} 1 \mathrm{H}\right), 7.17\left(\mathrm{dd},{ }^{3} J=8.5 \mathrm{~Hz},{ }^{4} J=2.0 \mathrm{~Hz}, 1 \mathrm{H}\right), 7.21\left(\mathrm{~d},{ }^{4} J=1.9 \mathrm{~Hz}, 1 \mathrm{H}\right)$, $7.32\left(\mathrm{td},{ }^{3} J=7.6 \mathrm{~Hz},{ }^{4} J=1.2 \mathrm{~Hz}, 1 \mathrm{H}\right), 8.97\left(\mathrm{~d},{ }^{3} J=8.5 \mathrm{~Hz}, 1 \mathrm{H}\right), 9.02\left(\mathrm{dd},{ }^{3} J=7.6 \mathrm{~Hz},{ }^{4} J=0.6 \mathrm{~Hz}, 1 \mathrm{H}\right)$, $10.9(\mathrm{~s}, 1 \mathrm{H}) .{ }^{13} \mathrm{C}-\mathrm{NMR}\left(100 \mathrm{MHz}, \mathrm{DMSO}, d_{6}\right) \delta \mathrm{ppm} 26.3,109.7,111.5,119.9,121.3,124.3,125.6,129.5$, 130.3, 130.9, 133.1, 134.3, 144.4, 146.2, 167.1, 168.9. Anal. calcd. for $\mathrm{C}_{17} \mathrm{H}_{11} \mathrm{BrN}_{2} \mathrm{O}_{2}: \mathrm{C}$ 57.49, $\mathrm{H} 3.12$, N 7.89; found: C 57.43, H 3.25, N 7.87. HRMS (ESI) calculated $m / z$ : 376.9896; found C17H11BrN2O2; $m / z: 376.9896[\mathrm{M}+\mathrm{H}]^{+}$.

\subsubsection{7-Bromo-1-Meisoindigo}

Yield: $40 \% .{ }^{1} \mathrm{H}-\mathrm{NMR}\left(400 \mathrm{MHz}, \mathrm{DMSO}, d_{6}\right) \delta \mathrm{ppm} 3.53(\mathrm{~s}, 3 \mathrm{H}), 6.8\left(\mathrm{~d},{ }^{3} J=7.7 \mathrm{~Hz}, 1 \mathrm{H}\right)$, $6.92\left(\mathrm{t},{ }^{3} \mathrm{~J}=8.0 \mathrm{~Hz}, 1 \mathrm{H}\right), 6.93(\mathrm{~m}, 1 \mathrm{H}), 7.23\left(\mathrm{td},{ }^{3} J=7.7 \mathrm{~Hz}{ }^{4} J=0.9 \mathrm{~Hz}, 1 \mathrm{H}\right), 7.52\left(\mathrm{dd},{ }^{3} J=8.0 \mathrm{~Hz}\right.$, $\left.{ }^{4} J=0.7 \mathrm{~Hz}, 1 \mathrm{H}\right), 8.92\left(\mathrm{~d},{ }^{3} \mathrm{~J}=8.0 \mathrm{~Hz}, 1 \mathrm{H}\right), 9.07\left(\mathrm{dd},{ }^{3} J=7.9 \mathrm{~Hz},{ }^{4} J=0.8 \mathrm{~Hz}, 1 \mathrm{H}\right), 10.9(\mathrm{~s}, 1 \mathrm{H})$. ${ }^{13} \mathrm{C}-\mathrm{NMR}\left(100 \mathrm{MHz}, \mathrm{DMSO}, d_{6}\right) \delta$ ppm 29.7, 101.3, 109.7, 121.2, 121.6, 123.0, 124.0, 127.9, 129.6, 130.6, 133.4, 135.1, 137.3, 141.6, 144.5, 167.5, 168.5. Anal. calcd. for $\mathrm{C}_{17} \mathrm{H}_{11} \mathrm{BrN}_{2} \mathrm{O}_{2}: \mathrm{C}$ 57.49, $\mathrm{H} 3.12$, N 7.89; found: C 57.86, H 3.03, N 7.91. HRMS (ESI) calculated $m / z: 376.9896$; found C17H11BrN2O2; $m / z: 376.9896[\mathrm{M}+\mathrm{H}]^{+}$.

\subsubsection{4'-Bromo-1-Meisoindigo}

Yield: 3.5\%. ${ }^{1} \mathrm{H}-\mathrm{NMR}\left(400 \mathrm{MHz}, \mathrm{DMSO}, d_{6}\right) \delta \mathrm{ppm} 3.2(\mathrm{~s}, 3 \mathrm{H}), 6.83\left(\mathrm{dd},{ }^{3} J=7.4 \mathrm{~Hz},{ }^{4} J=1.1 \mathrm{~Hz}\right.$, $1 \mathrm{H}), 7.03\left(\mathrm{~d},{ }^{3} J=7.8 \mathrm{~Hz}, 1 \mathrm{H}\right), 7.05\left(\mathrm{td},{ }^{3} J=8.1 \mathrm{~Hz}{ }^{4} J=1.0 \mathrm{~Hz}, 1 \mathrm{H}\right), 7.16\left(\mathrm{dd},{ }^{3} J=8.1 \mathrm{~Hz},{ }^{4} J=1.0 \mathrm{~Hz}, 1 \mathrm{H}\right)$, $7.21(\mathrm{~m}, 1 \mathrm{H}), 7.45\left(\mathrm{td},{ }^{3} J=7.8 \mathrm{~Hz},{ }^{4} J=1.0 \mathrm{~Hz}, 1 \mathrm{H}\right), 8.62\left(\mathrm{~d},{ }^{3} J=7.6 \mathrm{~Hz}, 1 \mathrm{H}\right), 10.93(\mathrm{~s}, 1 \mathrm{H}) .{ }^{13} \mathrm{C}-\mathrm{NMR}$ $\left(100 \mathrm{MHz}, \mathrm{DMSO}, d_{6}\right) \delta$ ppm 26.3, 108.7, 108.8, 121.2, 121.8, 122.4, 123.4, 126.3, 129.5, 131.7, 132.7, 133.0, 133.5, 145.4, 146.2, 165.1, 168.8. HRMS (ESI) calculated $m / z$ : 376.9896; found $\mathrm{C}_{17} \mathrm{H}_{11} \mathrm{BrN}_{2} \mathrm{O}_{2} ; m / z$ : $376.9896[\mathrm{M}+\mathrm{H}]^{+}$.

\subsubsection{5'-Bromo-1-Meisoindigo}

Yield: $80 \%$. ${ }^{1} \mathrm{H}-\mathrm{NMR}\left(400 \mathrm{MHz}, \mathrm{DMSO}, d_{6}\right) \delta \mathrm{ppm} 3.21(\mathrm{~s}, 3 \mathrm{H}), 6.97\left(\mathrm{~d},{ }^{3} \mathrm{~J}=8,3 \mathrm{~Hz}, 1 \mathrm{H}\right)$, $7.01\left(\mathrm{~d},{ }^{3} \mathrm{~J}=7.0 \mathrm{~Hz}, 1 \mathrm{H}\right), 7.03(\mathrm{~m}, 1 \mathrm{H}), 7.44\left(\mathrm{td},{ }^{3} \mathrm{~J}=7.7 \mathrm{~Hz},{ }^{4} \mathrm{~J}=1.2 \mathrm{~Hz}, 1 \mathrm{H}\right), 7.50\left(\mathrm{dd},{ }^{3} J=8.3 \mathrm{~Hz}\right.$, $\left.{ }^{4} J=2.1 \mathrm{~Hz}, 1 \mathrm{H}\right), 9.08\left(\mathrm{dd},{ }^{3} J=8.0 \mathrm{~Hz},{ }^{4} J=0.6 \mathrm{~Hz}, 1 \mathrm{H}\right), 9.33\left(\mathrm{~d},{ }^{4} J=2.0 \mathrm{~Hz}, 1 \mathrm{H}\right), 11.04(\mathrm{~s}, 1 \mathrm{H}) .{ }^{13} \mathrm{C}-\mathrm{NMR}$ $\left(100 \mathrm{MHz}, \mathrm{DMSO}, d_{6}\right) \delta$ ppm 26.6, 109.1, 111.8, 113.3, 121.0, 122.3, 123.8, 129.8, 131.9, 132.7, 133.6, 134.1, 135.2, 143.6, 145.8, 167.7, 168. Anal. calcd. for $\mathrm{C}_{17} \mathrm{H}_{11} \mathrm{BrN}_{2} \mathrm{O}_{2}$ : C 57.49, $\mathrm{H} 3.12, \mathrm{~N} 7.89$; found: $\mathrm{C} 57.34$, $\mathrm{H}$ 2.91, N 7.75, HRMS (ESI) calculated $m / z: 376.9896$; found $\mathrm{C}_{17} \mathrm{H}_{11} \mathrm{BrN}_{2} \mathrm{O}_{2} ; m / z: 376.9896[\mathrm{M}+\mathrm{H}]^{+}$.

\subsubsection{6'-Bromo-1-Meisoindigo}

Yield: 86\%. ${ }^{1} \mathrm{H}-\mathrm{NMR}\left(400 \mathrm{MHz}, \mathrm{DMSO}, d_{6}\right) \delta \mathrm{ppm} 3.17(\mathrm{~s}, 3 \mathrm{H}), 6.92\left(\mathrm{~d},{ }^{4} J=1.9 \mathrm{~Hz}, 1 \mathrm{H}\right)$, $6.95\left(\mathrm{~d},{ }^{3} \mathrm{~J}=7,8 \mathrm{~Hz}, 1 \mathrm{H}\right), 7.00(\mathrm{~m}, 1 \mathrm{H}), 7.11\left(\mathrm{dd},{ }^{3} \mathrm{~J}=8.6 \mathrm{~Hz},{ }^{4} \mathrm{~J}=2.0 \mathrm{~Hz}, 1 \mathrm{H}\right), 7.40\left(\mathrm{td},{ }^{3} \mathrm{~J}=7.7 \mathrm{~Hz}\right.$, 
$\left.{ }^{4} J=0.9 \mathrm{~Hz}, 1 \mathrm{H}\right), 8.97\left(\mathrm{~d},{ }^{3} \mathrm{~J}=8.6 \mathrm{~Hz}, 1 \mathrm{H}\right), 9.03\left(\mathrm{~d},{ }^{3} \mathrm{~J}=7.7 \mathrm{~Hz}, 1 \mathrm{H}\right), 11.0(\mathrm{~s}, 1 \mathrm{H}) .{ }^{13} \mathrm{C}-\mathrm{NMR}(100 \mathrm{MHz}$, DMSO, $\left.d_{6}\right) \delta$ ppm 26.0, 108.5, 112.2, 120.7, 121.8, 123.8, 125.5, 129.1, 130.9, 132.3, 132.8, 132.9, 145.1, 145.4, 167.1, 168.6. Anal. calcd. for $\mathrm{C}_{17} \mathrm{H}_{11} \mathrm{BrN}_{2} \mathrm{O}_{2}$ : C 57.49, $\mathrm{H} 3.12, \mathrm{~N} 7.89$; found: C 57.65, H 3.20, $\mathrm{N}$ 7.91. HRMS (ESI) calculated $m / z: 376.9896$; found $\mathrm{C}_{17} \mathrm{H}_{11} \mathrm{BrN}_{2} \mathrm{O}_{2} ; m / z: 376.9896[\mathrm{M}+\mathrm{H}]^{+}$.

\subsubsection{7'-Bromo-1-Meisoindigo}

Yield: 73\%. ${ }^{1} \mathrm{H}-\mathrm{NMR}\left(400 \mathrm{MHz}, \mathrm{DMSO}, d_{6}\right) \delta \mathrm{ppm} 3.21(\mathrm{~s}, 3 \mathrm{H}), 6.94\left(\mathrm{~d},{ }^{3} J=8.1 \mathrm{~Hz}, 1 \mathrm{H}\right)$, $7.03\left(\mathrm{~d},{ }^{3} \mathrm{~J}=7.6 \mathrm{~Hz}, 1 \mathrm{H}\right), 7.05\left(\mathrm{~m}, 1 \mathrm{H}, 7.45\left(\mathrm{td},{ }^{3} \mathrm{~J}=7.6 \mathrm{~Hz},{ }^{4} \mathrm{~J}=0.8 \mathrm{~Hz}, 1 \mathrm{H}\right), 7.55\left(\mathrm{dd},{ }^{3} \mathrm{~J}=7.9 \mathrm{~Hz}\right.\right.$, $\left.{ }^{4} J=0.5 \mathrm{~Hz}, 1 \mathrm{H}\right), 9.06\left(\mathrm{~d},{ }^{3} \mathrm{~J}=7.8 \mathrm{~Hz}, 1 \mathrm{H}\right), 9.10\left(\mathrm{dd},{ }^{3} \mathrm{~J}=8.0 \mathrm{~Hz},{ }^{4} J=0.6 \mathrm{~Hz}, 1 \mathrm{H}\right), 11.16(\mathrm{~s}, 1 \mathrm{H}) .{ }^{13} \mathrm{C}-\mathrm{NMR}$ $\left(100 \mathrm{MHz}, \mathrm{DMSO}, d_{6}\right) \delta$ ppm 26.1, 101.9, 108.6, 120.7, 121.9, 122.6, 123.3, 128.2, 129.2, 133.0, 133.2, 133.8, 135.1, 143.0, 145.3, 167.0, 168.6. Anal. calcd. for $\mathrm{C}_{17} \mathrm{H}_{11} \mathrm{BrN}_{2} \mathrm{O}_{2}$ : C 57.49, H 3.12, N 7.89; found: C 57.68, H 3.14, N 7.90. HRMS (ESI) calculated $m / z: 376.9896$; found C17H11BrN2O2; $m / z: 376.9896[\mathrm{M}+\mathrm{H}]^{+}$.

\subsection{Cell Culture}

HeLa and HCT116 were cultured in DMEM containing 10\% fetal bovine serum (FBS) and 1\% Penicillin/Streptomycin (Pen/Strep). JoPaca-1 cells were cultivated in RPMI 1640 medium supplemented with $10 \% \mathrm{FBS}$ and $1 \%$ Pen/Strep. Cells were kept under $5 \% \mathrm{CO}_{2}$ at $37{ }^{\circ} \mathrm{C}$ in a humidified atmosphere. Cells were treated with drugs solved in DMSO from Sigma-Aldrich (Germany) $24 \mathrm{~h}$ after seeding.

Human primary fibroblasts were isolated and cultivated as described previously with positive ethic permission $[59,60]$.

\subsection{Protein Kinase Profiling}

Protein kinase profiling was performed by ProQinase (Freiburg, Germany) as previously reported [5]. The kinase map was generated using KinMap beta developed by BioMedX (Heidelberg, Germany).

\subsection{Western Blotting}

As previously reported [18,59,60], $2 \times 10^{5}$ cells were seeded and treated with compounds for 30 min or $2 \mathrm{~h}$. Cells were lysed in Urea-lysis buffer containing $1 \mathrm{mM}$ EDTA, $0.5 \%$ Triton X-100, $5 \mathrm{mM}$ $\mathrm{NaF}, 6 \mathrm{M}$ Urea, $1 \mathrm{mM} \mathrm{Na} \mathrm{VO}_{4}, 10 \mathrm{mg} / \mathrm{mL}$ Pepstatin, $100 \mathrm{mM}$ PMSF, and $3 \mathrm{mg} / \mathrm{mL}$ Aprotinin in PBS. Protein concentrations were normalized to the smallest value and proteins were resolved on $8 \%$ SDS-PAGE and blotted to membrane using BlueFlash Large semi-dry blotter from Serva Electrophoresis (Heidelberg, Germany). The membrane was blocked for at least $2 \mathrm{~h}$ in $5 \%$ non-fat milk purchased form Roth (Karlsruhe, Germany) in TBS-T. For immunoblotting, all antibodies were applied according to manufacturers' recommendations. Immunoblots were developed with ECL solution obtained from PerkinElmar (Waltham, MA, USA) and imaged using digital imaging system LAS-3000 from Fujifilm (Tokyo, Japan).

\subsection{Cytotoxicity Assays}

$5 \times 10^{3}$ cells/well were seeded and treated in quadruplicates with compounds at concentrations ranging from $0.4 \mu \mathrm{M}$ to $100 \mu \mathrm{M}$ for 24,48 or $72 \mathrm{~h}$. Cells were incubated for $2 \mathrm{~h}$ in medium containing $1 \% \mathrm{FBS}$ and $0.5 \mathrm{mg} / \mathrm{mL}$ 3-(4,5-dimethylthiazol-2-yl)-2,5-diphenyltetrazolium bromide (MTT) bought from Sigma-Aldrich, washed in PBS, and incubated in DMSO from Honeywell (Morris Plains, NJ, USA) for 10 min shaking. Absorption was measured photometrically at $595 \mathrm{~nm}$ using Infinite F200 pro microplate reader from Tecan (Männedorf, Switzerland).

\subsection{CD133 and Annexin V Staining}

$2 \times 10^{5}$ cells/well were seeded and treated for $24 \mathrm{~h}$ with compounds. Cell were trypsinized and resuspended in $40 \mu \mathrm{L}$ blocking buffer obtained from Beckton, Dickinson and Company (Franklin Lakes, 
NJ, USA) and incubated for $10 \mathrm{~min}$ in the dark. $10 \mu \mathrm{L}$ staining solution containing CD133 antibody purchased from Miltenyi Biotec (Bergisch Gladbach, Germany) and Annexin V-FITC from eBioscience (San Diego, CA, USA) 1:10 in blocking buffer were added to each sample, which were then incubated for $15 \mathrm{~min}$ in the dark at room temperature. Finally, $450 \mathrm{~mL}$ FACS buffer obtained from Beckton, Dickinson and Company were added and the samples were immediately analyzed with a FACSCalibur device from Beckton, Dickinson and Company.

\subsection{Immunocytochemistry}

$5 \times 10^{3}$ cells/well were seeded and treated with compounds for $24 \mathrm{~h}$. Cells were fixed in $4 \%$ formaldehyde (formaldehyde 37\% from Merck (Darmstadt, Germany) in PBS) for 12 min and blocked for $60 \mathrm{~min}$ in blocking buffer (5\% goat serum, 1\% BSA, 0.3\% Triton X-100 in PBS). For immunostaining, all antibodies were applied according to manufacturers' recommendations. Photos were taken with Keyence BZ 9000 fluorescence microscope.

\section{9. $q R T-P C R$}

$2 \times 10^{5}$ cells/well were seeded and treated with compounds for 2 or $24 \mathrm{~h}$. RNA was isolated using NucleoSpin RNA Kit obtained from Macherey-Nagel (Düren, Germany) and cDNA synthesis was performed with ProtoScript II First Strand cDNA synthesis Kit using standard protocol from New England Biolabs (Ipswich, MA, United States). qPCR was performed according to manufacturers' recommendations in LightCycler 96 from Roche (Basel, Switzerland). Actin was used as reference gene for relative expression analysis which was performed as reported previously [61]. All primers were obtained from Eurofins Genomics (Luxembourg).The following primer pairs were used: ATF3 (5s: TCGGAGAAGCTGGAAAGTGT, 3as: TCTGGAGTCCTCCCATTCTG), c-Myc (5s: CCTGGCAAAAGGTCAGAGTC, 3as: GCTGCGTAGTTGTGCTGATG), IL-4 (5s: TTTGCTGCCT CCAAGAACAC, 3as: GTCGAGCCGTTTCAGGAATC), IL-6 (5s: AGACAGCCACTCACCTCTTC, 3as: AGTGCCTCTTTGCTGCTTTC), c-Jun (5s: TGAAACAGAGCATGACCCTG, 3as: GATTATCAGGC GCTCCAGCTC), MAFF (5s: TCTGTGGATCCCCTATCCAG, 3as: TCTGTGGATCCCCTATCCAG), p16 (5s: GAGCAGCATGGAGCCTTC, 3as: CATCATCATGACCTGGATCG), p21 (5s: GACACCACT GGAGGGTGACT, 3as: CAGGTCCACATGGTCTTCCT), $\beta$-actin (5s: CTGACTACCTCATGAAGA TCCTC, 3as; CATTGCCAATGGTGATGACCTG), Stat3 (5s: AGATGCAGCAGCTGGAACAGAT, 3as: CGTGAGAGTTTTCTGCACGT).

\subsection{Protein Microarray Analysis}

200,000 JoPaca-1 cells were seeded and treated for 30 min with 6-bromo-meisoindigo at the concentration of $10 \mu \mathrm{M}$ and $0.1 \%$ DMSO for mock treatment. Samples were collected and measured following ELISA-based microarray protocol previously described in Holenya et al. and using microarrays based on the ArrayStrip ${ }^{\mathrm{TM}}$ platform (Alere Technologies $\mathrm{GmbH}$, Jena, Germany) $[62,63]$. The quantity of phosphorylated proteins (ng/ $\mu \mathrm{g}$ of total protein) in 2-treated JoPaca-1 cells was compared to mock treatment and showed as fold change.

\section{Conclusions}

In this work, we identified that meisoindigo and 6-bromo-meisoindigo are potent Stat 3 inhibitors and kill CD133+ CSCs in tumors. Given that Stat3 and CD133 are of importance in the regulation of proliferation and development of chemotherapeutic resistance [22,34], our results suggest meisoindigos as promising anti-cancer agents. The recent results demonstrated that active Stat 3 led to the expression of immunosuppressive protein PD-L1, the major ligand of programmed death 1 (PD-1) [64]. It is very interesting if the combination of meisoindigos with a PD-1 or PD-L1 inhibitor can elicit a synergistic effect for immunotherapy. Moreover, our structure-activity relationship study also pinpoints that the 1- and 7-positions are available positions for further chemical modification. 
Supplementary Materials: The supplementary information is available online.

Acknowledgments: We thank Stefan Wölfl (IPMB, Heidelberg University) and Gerhard Eisenbrand (University of Kaiserslautern) for their outstanding support. This work was supported by DFG grant (CH 1690/2-1). We acknowledge the financial support of the Deutsche Forschungsgemeinschaft and Ruprecht-Karls-Universität Heidelberg within the funding programme Open Access Publishing.

Author Contributions: J.T. performed biological assessments and wrote the manuscript. R.B., S.S. and K.H.-M. synthesized compounds. B.B. performed protein microarray analysis. X.C. designed and performed experiments and wrote the manuscript.

Conflicts of Interest: The authors declare no conflict of interest.

\section{References}

1. Cheng, X.; Merz, K.H. The role of indirubins in inflammation and associated tumorigenesis. Adv. Exp. Med. Biol. 2016, 929, 269-290. [PubMed]

2. Xiao, Z.; Hao, Y.; Liu, B.; Qian, L. Indirubin and meisoindigo in the treatment of chronic myelogenous leukemia in china. Leuk. Lymphoma 2002, 43, 1763-1768. [CrossRef] [PubMed]

3. Cheng, X.; Merz, K.H.; Vatter, S.; Zeller, J.; Muehlbeyer, S.; Thommet, A.; Christ, J.; Wolfl, S.; Eisenbrand, G. Identification of a water-soluble indirubin derivative as potent inhibitor of insulin-like growth factor 1 receptor through structural modification of the parent natural molecule. J. Med. Chem. 2017, 60, 4949-4962. [CrossRef] [PubMed]

4. Vougogiannopoulou, K.; Ferandin, Y.; Bettayeb, K.; Myrianthopoulos, V.; Lozach, O.; Fan, Y.; Johnson, C.H.; Magiatis, P.; Skaltsounis, A.L.; Mikros, E.; et al. Soluble 3',6-substituted indirubins with enhanced selectivity toward glycogen synthase kinase -3 alter circadian period. J. Med. Chem. 2008, 51, 6421-6431. [CrossRef] [PubMed]

5. Cheng, X.; Rasque, P.; Vatter, S.; Merz, K.H.; Eisenbrand, G. Synthesis and cytotoxicity of novel indirubin-5-carboxamides. Bioorg. Med. Chem. 2010, 18, 4509-4515. [CrossRef] [PubMed]

6. Heshmati, N.; Cheng, X.; Dapat, E.; Sassene, P.; Eisenbrand, G.; Fricker, G.; Muellertz, A. In vitro and in vivo evaluations of the performance of an indirubin derivative, formulated in four different self-emulsifying drug delivery systems. J. Pharm. Pharmacol. 2014, 66, 1567-1575. [CrossRef] [PubMed]

7. Heshmati, N.; Cheng, X.; Eisenbrand, G.; Fricker, G. Enhancement of oral bioavailability of e804 by self-nanoemulsifying drug delivery system (snedds) in rats. J. Pharm. Sci. 2013, 102, 3792-3799. [CrossRef] [PubMed]

8. Heshmati, N.; Wagner, B.; Cheng, X.; Scholz, T.; Kansy, M.; Eisenbrand, G.; Fricker, G. Physicochemical characterization and in vitro permeation of an indirubin derivative. Eur. J. Pharm. Sci. 2013, 50, 467-475. [CrossRef] [PubMed]

9. Hoessel, R.; Leclerc, S.; Endicott, J.A.; Nobel, M.E.; Lawrie, A.; Tunnah, P.; Leost, M.; Damiens, E.; Marie, D.; Marko, D.; et al. Indirubin, the active constituent of a chinese antileukaemia medicine, inhibits cyclin-dependent kinases. Nat. Cell. Biol. 1999, 1, 60-67. [PubMed]

10. Cheng, X.; Alborzinia, H.; Merz, K.H.; Steinbeisser, H.; Mrowka, R.; Scholl, C.; Kitanovic, I.; Eisenbrand, G.; Wolfl, S. Indirubin derivatives modulate tgfbeta/bmp signaling at different levels and trigger ubiquitin-mediated depletion of nonactivated r-smads. Chem. Biol. 2012, 19, 1423-1436. [CrossRef] [PubMed]

11. Zuo, M.X.; Li, Y.; Zhou, J.H.; Wang, H.B.; Chen, X.G. Effect of meisoindigo on wnt signal pathway in k562 and hl-60 cells. Zhongguo Shi Yan Xue Ye Xue Za Zhi 2010, 18, 579-582. [PubMed]

12. Blazevic, T.; Heiss, E.H.; Atanasov, A.G.; Breuss, J.M.; Dirsch, V.M.; Uhrin, P. Indirubin and indirubin derivatives for counteracting proliferative diseases. Evid. Based Complement. Alternat. Med. 2015, 2015, 654098. [CrossRef] [PubMed]

13. Cheng, X.; Merz, K.H.; Vatter, S.; Christ, J.; Wolfl, S.; Eisenbrand, G. 7,7'-diazaindirubin-A small molecule inhibitor of casein kinase 2 in vitro and in cells. Bioorg. Med. Chem. 2014, 22, 247-255. [CrossRef] [PubMed]

14. Wee, X.K.; Yeo, W.K.; Zhang, B.; Tan, V.B.; Lim, K.M.; Tay, T.E.; Go, M.L. Synthesis and evaluation of functionalized isoindigos as antiproliferative agents. Bioorg. Med. Chem. 2009, 17, 7562-7571. [CrossRef] [PubMed] 
15. Fredebohm, J.; Boettcher, M.; Eisen, C.; Gaida, M.M.; Heller, A.; Keleg, S.; Tost, J.; Greulich-Bode, K.M.; Hotz-Wagenblatt, A.; Lathrop, M.; et al. Establishment and characterization of a highly tumourigenic and cancer stem cell enriched pancreatic cancer cell line as a well defined model system. PLOS ONE 2012, 7, e48503. [CrossRef] [PubMed]

16. Yin, A.H.; Miraglia, S.; Zanjani, E.D.; Almeida-Porada, G.; Ogawa, M.; Leary, A.G.; Olweus, J.; Kearney, J.; Buck, D.W. Ac133, a novel marker for human hematopoietic stem and progenitor cells. Blood 1997, 90, 5002-5012. [PubMed]

17. Hermann, P.C.; Huber, S.L.; Herrler, T.; Aicher, A.; Ellwart, J.W.; Guba, M.; Bruns, C.J.; Heeschen, C. Distinct populations of cancer stem cells determine tumor growth and metastatic activity in human pancreatic cancer. Cell Stem Cell 2007, 1, 313-323. [CrossRef] [PubMed]

18. Cheng, X.; Kim, J.Y.; Ghafoory, S.; Duvaci, T.; Rafiee, R.; Theobald, J.; Alborzinia, H.; Holenya, P.; Fredebohm, J.; Merz, K.H.; et al. Methylisoindigo preferentially kills cancer stem cells by interfering cell metabolism via inhibition of $\mathrm{lkb} 1$ and activation of ampk in pdacs. Mol. Oncol. 2016, 10, 806-824. [CrossRef] [PubMed]

19. Jordan, C.T.; Guzman, M.L.; Noble, M. Cancer stem cells. N. Engl. J. Med. 2006, 355, 1253-1261. [CrossRef] [PubMed]

20. Li, C.; Heidt, D.G.; Dalerba, P.; Burant, C.F.; Zhang, L.; Adsay, V.; Wicha, M.; Clarke, M.F.; Simeone, D.M. Identification of pancreatic cancer stem cells. Cancer Res. 2007, 67, 1030-1037. [CrossRef] [PubMed]

21. Lapidot, T.; Sirard, C.; Vormoor, J.; Murdoch, B.; Hoang, T.; Caceres-Cortes, J.; Minden, M.; Paterson, B.; Caligiuri, M.A.; Dick, J.E. A cell initiating human acute myeloid leukaemia after transplantation into scid mice. Nature 1994, 367, 645-648. [CrossRef] [PubMed]

22. Clevers, H. The cancer stem cell: Premises, promises and challenges. Nat. Med. 2011, 17, 313-319. [CrossRef] [PubMed]

23. Liu, L.; Kritsanida, M.; Magiatis, P.; Gaboriaud, N.; Wang, Y.; Wu, J.; Buettner, R.; Yang, F.; Nam, S.; Skaltsounis, L.; et al. A novel 7-bromoindirubin with potent anticancer activity suppresses survival of human melanoma cells associated with inhibition of stat3 and akt signaling. Cancer Biol. Ther. 2012, 13, 1255-1261. [CrossRef] [PubMed]

24. Liu, L.; Nam, S.; Tian, Y.; Yang, F.; Wu, J.; Wang, Y.; Scuto, A.; Polychronopoulos, P.; Magiatis, P.; Skaltsounis, L.; et al. 6-bromoindirubin-3'-oxime inhibits JAK/STAT3 signaling and induces apoptosis of human melanoma cells. Cancer Res. 2011, 71, 3972-3979. [CrossRef] [PubMed]

25. Meijer, L.; Skaltsounis, A.L.; Magiatis, P.; Polychronopoulos, P.; Knockaert, M.; Leost, M.; Ryan, X.P.; Vonica, C.A.; Brivanlou, A.; Dajani, R.; et al. Gsk-3-selective inhibitors derived from tyrian purple indirubins. Chem. Biol. 2003, 10, 1255-1266. [CrossRef] [PubMed]

26. Nam, S.; Buettner, R.; Turkson, J.; Kim, D.; Cheng, J.Q.; Muehlbeyer, S.; Hippe, F.; Vatter, S.; Merz, K.H.; Eisenbrand, G.; et al. Indirubin derivatives inhibit stat3 signaling and induce apoptosis in human cancer cells. Proc. Natl. Acad. Sci. USA 2005, 102, 5998-6003. [CrossRef] [PubMed]

27. Nam, S.; Scuto, A.; Yang, F.; Chen, W.; Park, S.; Yoo, H.S.; Konig, H.; Bhatia, R.; Cheng, X.; Merz, K.H.; et al. Indirubin derivatives induce apoptosis of chronic myelogenous leukemia cells involving inhibition of stat5 signaling. Mol. Oncol. 2012, 6, 276-283. [CrossRef] [PubMed]

28. Nam, S.; Wen, W.; Schroeder, A.; Herrmann, A.; Yu, H.; Cheng, X.; Merz, K.H.; Eisenbrand, G.; Li, H.; Yuan, Y.C.; et al. Dual inhibition of janus and src family kinases by novel indirubin derivative blocks constitutively-activated stat 3 signaling associated with apoptosis of human pancreatic cancer cells. Mol. Oncol. 2013, 7, 369-378. [CrossRef] [PubMed]

29. Silva, C.M. Role of stats as downstream signal transducers in src family kinase-mediated tumorigenesis. Oncogene 2004, 23, 8017-8023. [CrossRef] [PubMed]

30. Siveen, K.S.; Sikka, S.; Surana, R.; Dai, X.; Zhang, J.; Kumar, A.P.; Tan, B.K.; Sethi, G.; Bishayee, A. Targeting the stat3 signaling pathway in cancer: Role of synthetic and natural inhibitors. Biochim. Biophys. Acta. 2014, 1845, 136-154. [CrossRef] [PubMed]

31. Chen, C.L.; Hsieh, F.C.; Lieblein, J.C.; Brown, J.; Chan, C.; Wallace, J.A.; Cheng, G.; Hall, B.M.; Lin, J. Stat3 activation in human endometrial and cervical cancers. Br. J. Cancer 2007, 96, 591-599. [CrossRef] [PubMed]

32. Corvinus, F.M.; Orth, C.; Moriggl, R.; Tsareva, S.A.; Wagner, S.; Pfitzner, E.B.; Baus, D.; Kaufmann, R.; Huber, L.A.; Zatloukal, K.; et al. Persistent stat3 activation in colon cancer is associated with enhanced cell proliferation and tumor growth. Neoplasia 2005, 7, 545-555. [CrossRef] [PubMed] 
33. Wei, D.; Le, X.; Zheng, L.; Wang, L.; Frey, J.A.; Gao, A.C.; Peng, Z.; Huang, S.; Xiong, H.Q.; Abbruzzese, J.L.; et al. Stat 3 activation regulates the expression of vascular endothelial growth factor and human pancreatic cancer angiogenesis and metastasis. Oncogene 2003, 22, 319-329. [CrossRef] [PubMed]

34. Kamran, M.Z.; Patil, P.; Gude, R.P. Role of stat3 in cancer metastasis and translational advances. Biomed. Res. Int. 2013, 2013, 421821. [CrossRef] [PubMed]

35. Lin, L.; Jou, D.; Wang, Y.; Ma, H.; Liu, T.; Fuchs, J.; Li, P.K.; Lu, J.; Li, C.; Lin, J. Stat3 as a potential therapeutic target in ALDH+ and CD44+/CD24+ stem cell-like pancreatic cancer cells. Int. J. Oncol. 2016, 49, 2265-2274. [CrossRef] [PubMed]

36. Civenni, G.; Malek, A.; Albino, D.; Garcia-Escudero, R.; Napoli, S.; Di Marco, S.; Pinton, S.; Sarti, M.; Carbone, G.M.; Catapano, C.V. Rnai-mediated silencing of myc transcription inhibits stem-like cell maintenance and tumorigenicity in prostate cancer. Cancer Res. 2013, 73, 6816-6827. [CrossRef] [PubMed]

37. Cartwright, P.; McLean, C.; Sheppard, A.; Rivett, D.; Jones, K.; Dalton, S. Lif/stat3 controls es cell self-renewal and pluripotency by a myc-dependent mechanism. Development 2005, 132, 885-896. [CrossRef] [PubMed]

38. Yu, H.; Lee, H.; Herrmann, A.; Buettner, R.; Jove, R. Revisiting stat3 signalling in cancer: New and unexpected biological functions. Nat. Rev. Cancer 2014, 14, 736-746. [CrossRef] [PubMed]

39. Yu, H.; Pardoll, D.; Jove, R. Stats in cancer inflammation and immunity: A leading role for stat3. Nat. Rev. Cancer 2009, 9, 798-809. [CrossRef] [PubMed]

40. Rho, O.; Kim, D.J.; Kiguchi, K.; Digiovanni, J. Growth factor signaling pathways as targets for prevention of epithelial carcinogenesis. Mol. Carcinog 2011, 50, 264-279. [CrossRef] [PubMed]

41. Kim, M.S.; Lee, W.S.; Jeong, J.; Kim, S.J.; Jin, W. Induction of metastatic potential by TrkB via activation of IL6/JAK2/STAT3 and Pi3k/Akt signaling in breast cancer. Oncotarget 2015, 6, 40158-40171. [CrossRef] [PubMed]

42. Leonis, M.A.; Thobe, M.N.; Waltz, S.E. Ron-receptor tyrosine kinase in tumorigenesis and metastasis. Future Oncol. 2007, 3, 441-448. [CrossRef] [PubMed]

43. Schuringa, J.J.; Wojtachnio, K.; Hagens, W.; Vellenga, E.; Buys, C.H.; Hofstra, R.; Kruijer, W. Men2a-retinduced cellular transformation by activation of stat3. Oncogene 2001, 20, 5350-5358. [CrossRef] [PubMed]

44. Yi, Z.; Li, L.; Matsushima, G.K.; Earp, H.S.; Wang, B.; Tisch, R. A novel role for c-src and stat3 in apoptotic cell-mediated mertk-dependent immunoregulation of dendritic cells. Blood 2009, 114, 3191-3198. [CrossRef] [PubMed]

45. Alvarez, J.V.; Greulich, H.; Sellers, W.R.; Meyerson, M.; Frank, D.A. Signal transducer and activator of transcription 3 is required for the oncogenic effects of non-small-cell lung cancer-associated mutations of the epidermal growth factor receptor. Cancer Res. 2006, 66, 3162-3168. [CrossRef] [PubMed]

46. Cao, X.; Tay, A.; Guy, G.R.; Tan, Y.H. Activation and association of stat 3 with src in v-src-transformed cell lines. Mol. Cell. Biol. 1996, 16, 1595-1603. [CrossRef] [PubMed]

47. Werdich, X.Q.; Penn, J.S. Src, fyn and yes play differential roles in vegf-mediated endothelial cell events. Angiogenesis 2005, 8, 315-326. [CrossRef] [PubMed]

48. Zoubeidi, A.; Rocha, J.; Zouanat, F.Z.; Hamel, L.; Scarlata, E.; Aprikian, A.G.; Chevalier, S. The fer tyrosine kinase cooperates with interleukin-6 to activate signal transducer and activator of transcription 3 and promote human prostate cancer cell growth. Mol. Cancer Res. 2009, 7, 142-155. [CrossRef] [PubMed]

49. Nelson, K.L.; Rogers, J.A.; Bowman, T.L.; Jove, R.; Smithgall, T.E. Activation of stat3 by the c-fes protein-tyrosine kinase. J. Biol. Chem. 1998, 273, 7072-7077. [CrossRef] [PubMed]

50. Liu, L.; Gao, Y.; Qiu, H.; Miller, W.T.; Poli, V.; Reich, N.C. Identification of stat3 as a specific substrate of breast tumor kinase. Oncogene 2006, 25, 4904-4912. [CrossRef] [PubMed]

51. Lim, C.P.; Cao, X. Structure, function, and regulation of stat proteins. Mol. Biosyst 2006, 2, 536-550. [CrossRef] [PubMed]

52. Carpenter, R.L.; Lo, H.W. Stat3 target genes relevant to human cancers. Cancers (Basel) 2014, 6, 897-925. [CrossRef] [PubMed]

53. Dauer, D.J.; Ferraro, B.; Song, L.; Yu, B.; Mora, L.; Buettner, R.; Enkemann, S.; Jove, R.; Haura, E.B. Stat3 regulates genes common to both wound healing and cancer. Oncogene 2005, 24, 3397-3408. [CrossRef] [PubMed]

54. Cho, S.-D.; Li, G.; Hu, H.; Jiang, C.; Kang, K.-S.; Lee, Y.-S.; Kim, S.-H.; Lu, J. Involvement of c-jun n-terminal kinase in $\mathrm{g}^{2} / \mathrm{m}$ arrest and caspase-mediated apoptosis induced by sulforaphane in du145 prostate cancer cells. Nutr. Cancer 2005, 52, 213-224. [CrossRef] [PubMed] 
55. Wisdom, R.; Johnson, R.S.; Moore, C. C-jun regulates cell cycle progression and apoptosis by distinct mechanisms. EMBO J. 1999, 18, 188-197. [CrossRef] [PubMed]

56. Kannan, M.B.; Solovieva, V.; Blank, V. The small maf transcription factors maff, mafg and mafk: Current knowledge and perspectives. Biochim. Biophys. Acta. 2012, 1823, 1841-1846. [CrossRef] [PubMed]

57. Camarda, R.; Williams, J.; Goga, A. In vivo reprogramming of cancer metabolism by myc. Front. Cell Dev. Biol. 2017, 5, 35. [CrossRef] [PubMed]

58. Hao, Z.F.; Ao, J.H.; Zhang, J.; Su, Y.M.; Yang, R.Y. Atf3 activates stat3 phosphorylation through inhibition of p53 expression in skin cancer cells. Asian Pac. J. Cancer Prev. 2013, 14, 7439-7444. [CrossRef] [PubMed]

59. Cheng, X.; Dimou, E.; Alborzinia, H.; Wenke, F.; Gohring, A.; Reuter, S.; Mah, N.; Fuchs, H.; Andrade-Navarro, M.A.; Adjaye, J.; et al. Identification of 2-[4-[(4-methoxyphenyl)methoxy]-phenyl] acetonitrile and derivatives as potent Oct3/4 inducers. J. Med. Chem. 2015, 58, 4976-4983. [CrossRef] [PubMed]

60. Cheng, X.; Yoshida, H.; Raoofi, D.; Saleh, S.; Alborzinia, H.; Wenke, F.; Gohring, A.; Reuter, S.; Mah, N.; Fuchs, H.; et al. Ethyl 2-((4-chlorophenyl)amino)thiazole-4-carboxylate and derivatives are potent inducers of oct3/4. J. Med. Chem. 2015, 58, 5742-5750. [CrossRef] [PubMed]

61. Schmittgen, T.D.; Livak, K.J. Analyzing real-time PCR data by the comparative C(t) method. Nat. Protoc. 2008, 3, 1101-1108. [CrossRef] [PubMed]

62. Cheng, X.; Holenya, P.; Can, S.; Alborzinia, H.; Rubbiani, R.; Ott, I.; Wolfl, S. A TrxR inhibiting gold(i) NHC complex induces apoptosis through ASK1-p38-MAPK signaling in pancreatic cancer cells. Molecular Cancer 2014, 13, 221. [CrossRef] [PubMed]

63. Holenya, P.; Can, S.; Rubbiani, R.; Alborzinia, H.; Junger, A.; Cheng, X.; Ott, I.; Wolfl, S. Detailed analysis of pro-apoptotic signaling and metabolic adaptation triggered by a $n$-heterocyclic carbene-gold(i) complex. Metallomics 2014, 6, 1591-1601. [CrossRef] [PubMed]

64. Marzec, M.; Zhang, Q.; Goradia, A.; Raghunath, P.N.; Liu, X.; Paessler, M.; Wang, H.Y.; Wysocka, M.; Cheng, M.; Ruggeri, B.A.; et al. Oncogenic kinase NPM/ALK induces through stat3 expression of immunosuppressive protein CD274 (PD-11, B7-H1). Proc. Natl. Acad. Sci. USA 2008, 105, 20852-20857. [CrossRef] [PubMed]

Sample Availability: Samples of meisoindigo derivatives are available are available from the authors.

(C) 2017 by the authors. Licensee MDPI, Basel, Switzerland. This article is an open access article distributed under the terms and conditions of the Creative Commons Attribution (CC BY) license (http:// creativecommons.org/licenses/by/4.0/). 